\title{
Signal Transduction Systems Mediated by Protein Kinase-C and Estradiol Receptors in Cow Placenta and Caruncle
}

\author{
Norio KATOH \\ Hokkaido Branch Laboratory, National Institute of Animal Health, Hitsujigaoka 4, Sapporo 062, Japan
}

(Received 29 August 1991/Accepted 23 October 1991)

\begin{abstract}
Characteristics of signal transduction systems mediated by protein kinase-C $\left(\mathrm{Ca}^{2+} /\right.$ phospholipid-dependent protein kinase) and estradiol receptors in cow placenta and caruncle were conducted by evaluating protein kinase-C activity and estradiol receptor concentrations and by exploring substrate proteins for the enzyme. The enzyme activity was detected in cytosolic and total particulate fractions of both tissues. The activity levels in these fractions were comparable to those in other cow tissues such as liver and mammary gland. The enzyme activity was inhibited by palmitoylcarnitine, gossypol and adriamycin, known phospholipid-interacting inhibitors of the enzyme. Phosphorylation by the enzyme and subsequent autoradiography revealed that only $125 \mathrm{~K}$ protein in placental cytosol and two low molecular weight proteins in caruncular cytosol were found to be substrates for protein kinase-C. $\mathrm{Ca}^{2+}$ acts as inhibitor of the phosphorylation of several phosphoproteins other than the substrates. Estradiol receptor concentrations in cytosolic and nuclear fractions were similar in both tissues, and the cytosolic concentrations were also comparable to those in pregnant uterus. However, the nuclear concentrations were extremely low when compared to those in the uterus. The signal transduction systems mediated by protein kinase- $\mathrm{C}$ and by estradiol receptors seem to be concertedly suppressed in cow placenta and caruncle.-KEY wORDS: caruncle, estradiol receptor, placenta, protein kinase-C.
\end{abstract}

J. Vet. Med.Sci. 54(1): 81-86, 1992

Extracellular signal molecules such as hormones and growth factors bind to their respective receptors which are located at the cell surface or in cytoplasm. After mediation by receptors of signals from the first messengers, second messengers are produced or increased intracellularly. The second messengers include cyclic AMP, $\mathrm{Ca}^{2+}$ and diacylglycerols. The diacylglycerols activate protein kinase-C (PKC). Other than diacylglycerols, PKC requires $\mathrm{Ca}^{2+}$ and membrane-bound phospholipids, particularly, phosphatidylserine (PS) for its activation. The diacylglycerols increase the affinity of PKC for $\mathrm{Ca}^{2+}$ as well as for PS, thereby activating PKC [18]. The activated PKC phosphorylates intracellular substrate proteins, and the phosphorylated proteins regulate diverse cellular functions [17].

Steroid hormones pass through the plasma membrane and bind to their intracellular receptors. The hormone-receptor complex is transported into nuclei, then binds to DNA to regulate gene expression, leading to synthesis of specific proteins responsible for cellular regulation [19]. Phosphorylation by $\mathrm{PKC}$ of rat corpus luteum protein is reported to be modulated by estradiol $\left(\mathrm{E}_{2}\right)$ [22]. Furthermore, $\mathrm{E}_{2}$ inhibits rat uterine protein phosphorylation catalyzed by PKC after $E_{2}$ administration (Katoh, unpublished work), suggesting an intimate relationship between the signal transduction systems mediated by $\mathrm{PKC}$ and $\mathrm{E}_{2}$ receptors.

Placenta is a tissue specified for transportation between the mother and fetus of nutrients. Placenta also acts as an immune-barrier for the survival of fetal allografts [6]. In despite of their importance, few reports have been published on the signal transduction systems, particularly those mediated by $\mathrm{PKC}$ in cow placenta. In the present study, PKC activity, as well as $\mathrm{E}_{2}$ receptor concentrations, were evaluated in cow placenta and caruncle (Carunculae uterinae). The endogenous substrate proteins for $\mathrm{PKC}$ are also explored in both tissues.

\section{MATERIALS AND METHODS}

Chemicals: $\left[\gamma_{-}{ }^{32} \mathrm{P}\right] \mathrm{ATP}(0.37 \mathrm{TBq} / \mathrm{mmol})$ and $\left[2,4,6,7-{ }^{3} \mathrm{H}(\mathrm{N})\right] \mathrm{E}_{2}$ were purchased from New England Nuclear (Boston, MA, U.S.A.). PS, lysine-rich histone (type III-S), $E_{2}$, diethylstilbestrol (DES), DL-palmitoylcarnitine and gossypol were from Sigma (St. Louis, MO, U.S.A.). Adriamycin was from Kyowa Hakko Kogyo (Tokyo, Japan). Hydroxylapatite (DNA grade) was from BioRad (Richmond, CA, U.S.A.). Other reagents were of analytical grade.

Tissues: Placentae from 5-6-month pregnant Holstein cows were collected from a local slaughter house. Placenta and caruncle were separated, and 
both were immediately cooled in ice and transported to the laboratory.

Subcellular fractionation: For the $\mathrm{E}_{2}$ receptor assay, fresh placenta and caruncle were used. The tissues were homogenized in 9 volumes of TEDG buffer (10 mM Tris/Cl, pH 7.5, 1 mM EDTA, 1 mM dithiothreitol and $10 \%$ glycerol) containing $1 \mathrm{mM}$ phenylmethylsulfonyl fluoride (PMSF) using a Polytron PTA-10S (5 sec at setting 5) and subsequently using a Teflon-glass homogenizer ( 5 strokes at $c a .1,600 \mathrm{rpm}$ ). The homogenate was centrifuged at $800 \times \mathrm{g}$ for $10 \mathrm{~min}$ to precipitate nuclei. The supernatant obtained was further centrifuged at $105,000 \times \mathrm{g}$ for $60 \mathrm{~min}$, and the resulting supernatant was used as cytosol. The crude nuclei precipitated by the first centrifugation were suspended in TMD buffer (10 mM Tris/Cl, pH 7.5, $5 \mathrm{mM} \mathrm{MgCl}_{2}$ and 1 $\mathrm{mM}$ dithiothreitol) containing $2 \mathrm{M}$ sucrose, and then centrifuged at $50,000 \times \mathrm{g}$ for $60 \mathrm{~min}$. Precipitated nuclei were washed 3 times with TMD buffer.

For the PKC assay, tissues frozen at $-80^{\circ} \mathrm{C}$ were used. The tissues were thawed and homogenized in 9 volumes of $0.25 \mathrm{M}$ sucrose, $20 \mathrm{mM}$ Tris/Cl, $\mathrm{pH}$ 7.5, $2.5 \mathrm{mM}$ EGTA and $50 \mathrm{mM}$ 2-mercaptoethanol. The homogenate was centrifuged at $105,000 \times \mathrm{g}$ for $60 \mathrm{~min}$ to prepare cytosol. The precipitate suspended in the original volume of the sucrose buffer was treated with $0.1 \%$ Triton $\mathrm{X}-100$ at $4^{\circ} \mathrm{C}$ for 60 $\min [15]$. The supernatant obtained by centrifugation at $105,000 \times \mathrm{g}$ for $60 \mathrm{~min}$ was used as the (solubilized) total particulate fraction.

$P K C$ assay: PKC was assayed as described previously [15]. The reaction mixture $(200 \mu l)$ contained $25 \mathrm{mM}$ Tris/Cl (pH 7.5), $10 \mathrm{mM} \mathrm{MgCl} 2,0.5$ $\mathrm{mM} \mathrm{CaCl} 2,0.25 \mathrm{mM}$ EGTA, $40 \mu \mathrm{g}$ of histone, 50 $\mu \mathrm{M}\left[\gamma_{-}{ }^{32} \mathrm{P}\right] \mathrm{ATP}$, and an appropriate amount of sample protein in the absence or presence of $5 \mu \mathrm{g}$ of PS. The reaction was initiated by the addition of ATP and proceeded for $5 \mathrm{~min}$ at $30^{\circ} \mathrm{C}$, which is within the linear phase of the time course. PKC activity was determined by the subtraction of basal activity obtained in the absence of PS. All assays were done in duplicate.

Autoradiography: Endogenous PKC in the subcellular fractions was used for phosphorylation of placenta and caruncle proteins. The reaction conditions were the same as those described for the PKC assay except that histone was deleted and the volume of ATP was increased from $6 \mu l(1.67 \mathrm{mM})$ to $30 \mu l(0.333 \mathrm{mM})$. The reaction was allowed to continue for $5 \mathrm{~min}$ and was terminated by stop solution [15]. SDS-polyacrylamide gel electrophoresis was then perfomed using $12 \%$ gels. After electrophoresis, gels were stained with Coomassie brilliant blue, destained, dried, and exposed to Kodak X-omat AR film for 7-10 days at $-80^{\circ} \mathrm{C}$ with the aid of a DuPont Hi-Plus intensifying screen.

$E_{2}$ receptor assay: This was done as described recently $[9,11]$. Briefly, cytosol $(200 \mu l)$ was mixed with a final concentration of $5 \mathrm{nM}\left[{ }^{3} \mathrm{H}\right] \mathrm{E}_{2}$ in the absence (total binding) or presence (non-specific binding) of a 100-fold molar excess of DES in a final volume of $300 \mu \mathrm{l}$. The mixture was incubated overnight at $4^{\circ} \mathrm{C}$ and thereafter treated with $1 \mathrm{ml}$ of dextran-coated charcoal. After centrifugation at $1,800 \times \mathrm{g}$ for $10 \mathrm{~min}$, the supernatant $(1 \mathrm{ml})$ was mixed with $10 \mathrm{~m} l$ of scintillation mixture and then counted. The specific receptor concentrations were determined by the subtraction of non-specific binding from total binding. All assays were done in triplicate.

Nuclear $E_{2}$ receptor assay was followed the method of Beckman et al. [2]. Nuclei $(290 \mu l)$ were mixed with $5 \mathrm{nM}\left[{ }^{3} \mathrm{H}\right] \mathrm{E}_{2}$ without or with a 100 -fold molar excess of DES, and incubated at $37^{\circ} \mathrm{C}$ for 30 min. Hydroxylapatite suspension $(0.5 \mathrm{ml})$ was then added to the mixture and it was incubated for $15 \mathrm{~min}$ in ice. After washing with TMD buffer, the suspension was extracted with $3 \mathrm{~m} l$ of ethanol. Radioactivity in the extract was measured as described above.

Other methods: Protein was determined by the method of Bradford [4] using ovalbumin as the standard. DNA was determined according to the method of Burton [5] using calf thymus DNA as the standard. Statitical significance was analyzed by Student's $t$-test. Values were expressed as mean \pm S.E.

\section{RESULTS}

Direct PKC assays of crude extracts such as cytosol and total particulate fraction lead to imprecise evaluation of PKC activity, because PKC is affected by a wide variety of endogenous molecules, including carnitines [13], polyamines [20], sphingosines [7] and calmodulin [1]. To remove these molecules, the use of DEAE-cellulose chromatography has been recommended [14]. In the present study, cytosolic and total particulate fractions of both placenta and caruncle were separately charged to a DEAE-cellulose column and the PKC bound 
Table 1. Protein kinase-C activity in cytosolic and total particulate fractions of cow placenta and caruncle

\begin{tabular}{lccc}
\hline Tissue & $\mathrm{n}$ & Cytosol & Total particulate \\
\hline Placenta & 3 & $1.92 \pm 0.53$ & $3.07 \pm 2.38$ \\
Caruncle & 3 & $4.77 \pm 1.56$ & $5.40 \pm 3.70$ \\
Liver & 5 & $2.78 \pm 0.75$ & $0.71 \pm 0.25$ \\
Mammary gland & 5 & $1.42 \pm 0.24$ & $4.11 \pm 1.12$ \\
\hline
\end{tabular}

$\mathrm{nmol} / \mathrm{min} / \mathrm{g}$ tissue

Cytosolic and total particulate fractions from $2-3 \mathrm{~g}$ of the tissues were charged separately to a DE-52 column $(2 \times 20$ $\mathrm{cm})$ which had been equilibrated with $20 \mathrm{mM}$ Tris/ $\mathrm{Cl}(\mathrm{pH}$ 7.5), $1 \mathrm{mM}$ EDTA and $50 \mathrm{mM}$ 2-mercaptoethanol, then eluted with a linear gradient of $\mathrm{NaCl}(0-0.5 \mathrm{M}$; total 300 $\mathrm{m} l)$. An aliquot $(20 \mu l)$ of each eluant was assayed for PKC, and activity levels were summed to obtain total activity. For comparison, the values from cow liver [10] and mammary gland [8], which were obtained in a manner similar to that in the present study, are presented in this Table.
Table 2. Effects of palmitoylcarnitine, gossypol and adriamycin on PKC in cytosolic fractions of cow placenta and caruncle

\begin{tabular}{lccc}
\hline Tissue & $\begin{array}{c}\text { Inhibitor } \\
(100 \mu \mathrm{M})\end{array}$ & $\begin{array}{c}\text { PKC activity } \\
(\mathrm{pmol} / \mathrm{min})\end{array}$ & $\%$ of the activity \\
\hline Placenta & - & 12.3 & 100 \\
& PC & 0.6 & 5 \\
& Gossypol & 0.9 & 7 \\
Caruncle & Adriamycin & 10.8 & 87 \\
& - & 12.5 & 100 \\
& PC & 0 & 0 \\
& Gossypol & 0 & 0 \\
& Adriamycin & 10.3 & 82 \\
\hline
\end{tabular}

DEAE-cellulose chromatographed cytosolic fractions were used in this experiment. Palmitoylcarnitine (PC) and adriamycin were dissolved in water, whereas gossypol was dissolved in $10 \mathrm{mM}$ sodium carbonate buffer ( $\mathrm{pH}$ 8.3) as described [16], and included in the reaction mixture.

\section{$\begin{array}{llllllll}1 & 2 & 3 & 4 & 5 & 6 & 7 & 8\end{array}$}

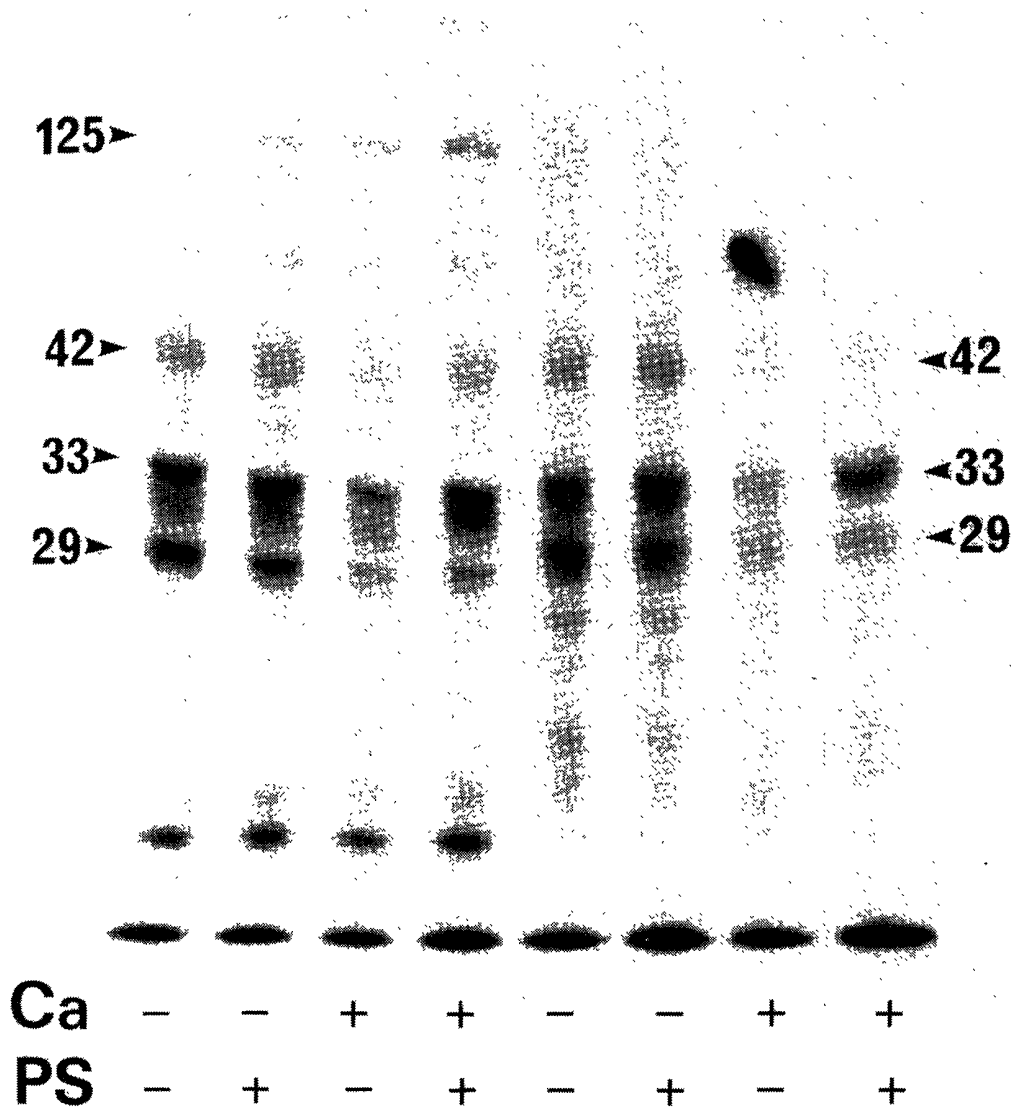

Fig. 1. Autoradiogram showing phosphorylation of cow placental proteins by PKC. 1-4, cytosol; $5-8$, total particulate fraction. Numbers on both sides indicate molecular weight $(\mathrm{kDa}$.). The spot in lane 7 was an artifact due to radiolabelled ATP. 


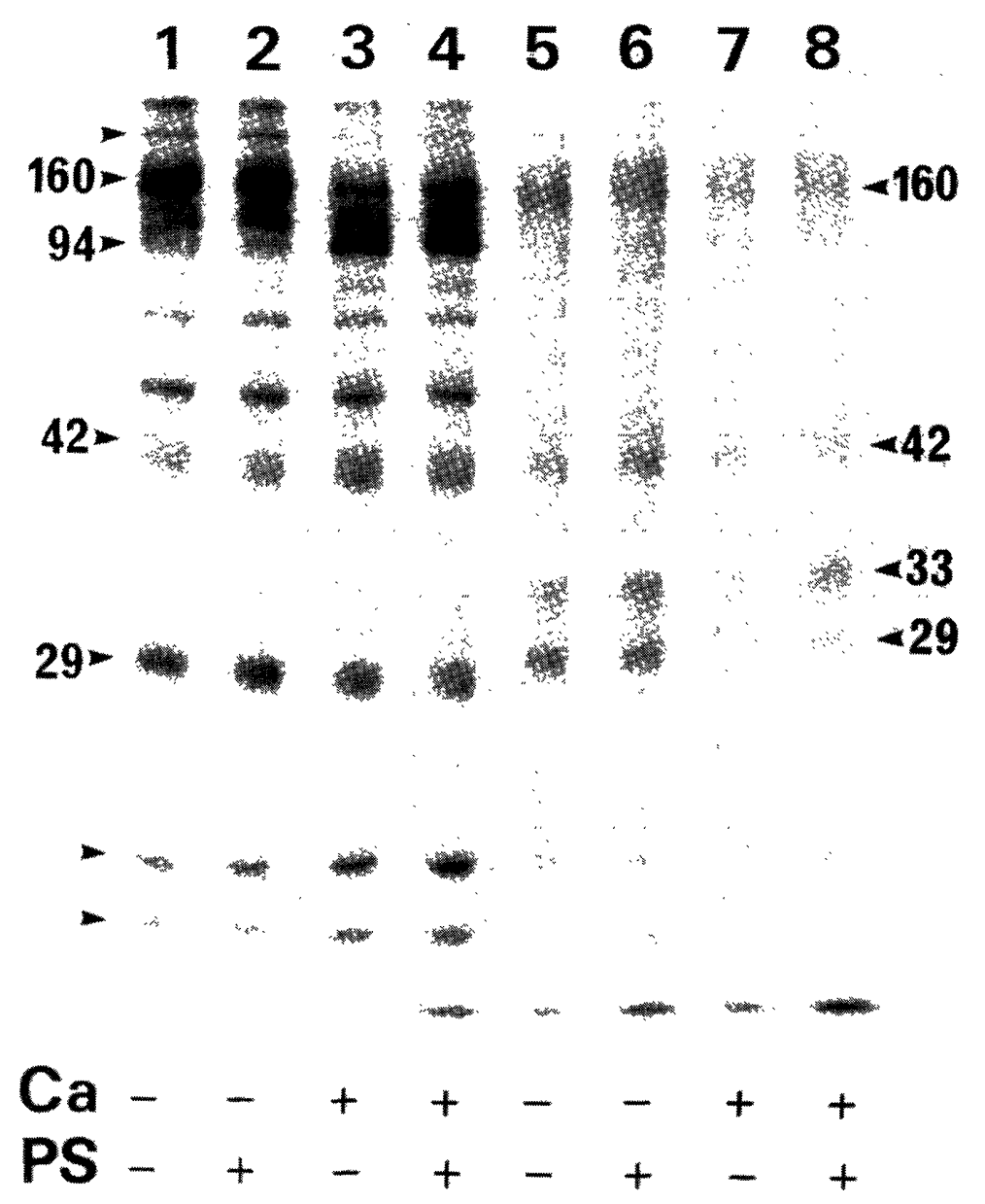

Fig. 2. Autoradiogram showing phosphorylation of cow caruncle proteins by PKC. 1-4, cytosol; 5-8, total particulate fraction. Other conditons were as described in Fig. 1.

was eluted by an $\mathrm{NaCl}$ gradient, after which $\mathrm{PKC}$ activity in the eluants was evaluated (Table 1). PKC activity was detected in cytosolic and total particulate fractions of both tissues. The levels in the fractions were comparable to those in cow liver [10] and mammary gland [8]. Although not significant, placental and caruncular PKC activity appeared to be more abundant in the total particulate fraction than in the cytosolic fraction. The predominant distributions in total particulate fractions were similar to that of mammary gland [8].

Effects of palmitoylcarnitine, gossypol and adriamycin on cytosolic PKC from placenta and caruncle are shown in Table 2. These compounds are known to bind with the regulatory domain of PKC and, as a consequence, inhibit competitively with respect to the cofactors, particularly with PS $[12,13,16]$. Palmitoylcarnitine and gossypol strongly inhibited PKC from both tissues. Adriaymcin, although less effective, also inhibited the enzyme. Total particulate PKC from both tissues was similarly inhibited by the three compounds (data not shown). By the results obtained from the experiment using inhibitors, the presence of PKC $\left(\mathrm{Ca}^{2+} /\right.$ phospholipid-dependent protein kinase) was confirmed in cytosolic and total particulate fractions of both placenta and caruncle.

Figure 1 shows phosphorylation of placental proteins by endogenous $\mathrm{PKC}$. A $125 \mathrm{~K}$ protein in cytosol was found to be a substrate for $\mathrm{PKC}$, because $125 \mathrm{~K}$ phosphorylation was stimulated by the simultaneous presence of $\mathrm{Ca}^{2+}$ and PS. Except for this $125 \mathrm{~K}$, placenta had no PKC substrate. Phosphorylation of $42 \mathrm{~K}, 33 \mathrm{~K}$ and $29 \mathrm{~K}$ proteins in both fractions was reduced by $\mathrm{Ca}^{2+}$. The reduced phosphorylation was partially restored by the addition of PS, particularly in the cytosolic $42 \mathrm{~K}$ and particulate $33 \mathrm{~K}$ (compare lanes 3 and 4 , and 7 and 
Table 3. $\mathrm{E}_{2}$ receptor concentrations in cytosolic and nuclear fractions of cow placenta, caruncle and pregnant uterus

\begin{tabular}{lccr}
\hline Tissue & $\mathrm{n}$ & Cytosol & \multicolumn{1}{c}{ Nuclei } \\
\hline Placenta & 3 & $5.08 \pm 1.78$ & $36.8 \pm 7.8$ \\
Caruncle & 3 & $3.49 \pm 2.12$ & $32.1 \pm 6.3$ \\
Uterus & 3 & $4.77 \pm 1.26$ & $161 \pm 23.3$
\end{tabular}

$\mathrm{fmol} / \mathrm{mg}$ protein (cytosol) and fmol/mg DNA (nuclei)

8).

In phosphorylation of caruncular proteins, two low molecular weight proteins in cytosol (indicated by arrows at the bottom of left side; these molecular weights were less than myoglobin, $18.5 \mathrm{~K}$ ) were shown to be substrates for PKC (Fig. 2). Phosphorylation of a high molecular weight protein in cytosol (indicated by the arrow at the top; this was larger than myosin heavy chain, $205 \mathrm{~K}$ ), $160 \mathrm{~K}$ in both fractions, and $42 \mathrm{~K}, 33 \mathrm{~K}$ and $29 \mathrm{~K}$ in the particulate fraction, was reduced by $\mathrm{Ca}^{2+}$, as in the case of placenta. The reduced phosphorylation was also partially restored by PS in the particulate $33 \mathrm{~K}$. A $94 \mathrm{~K}$ phosphorylation was stimualted by $\mathrm{Ca}^{2+}$ but not by PS, indicating that this was phosphorylase $b$ [15].

$E_{2}$ receptor concentrations of placenta and caruncle were evaluated (Table 3 ). The receptor concentrations in cytosol and nuclei of both tissues were similar. When compared to those of pregnant uterus, a striking difference was observed in the nuclear recpetor concentrations. The nuclear concentrations were extremely low in placenta and caruncle, whereas the cytosolic concentrations were comparable in both tissues and uterus.

\section{DISCUSSION}

In the present study, $\mathrm{PKC}$ activity and $\mathrm{E}_{2}$ receptor concentrations were evaluated and substrates for PKC were also explored in cow placenta and caruncle. The most striking finding is that both tissues have few substrates for PKC, in spite of the fact that both tissues contain PKC activity comparable to that in other cow tissues such as mammary gland. In cow mammary gland, more than four substrate proteins for PKC can be easily detected by the similar autoradiographic analysis [8]. In addition to the few substrate species, $\mathrm{Ca}^{2+}$ acts as inhibitor towards several phosphoproteins $(42 \mathrm{~K}, 33 \mathrm{~K}$ and $29 \mathrm{~K}$ in placenta, and a protein having a molecular weight of more than $205 \mathrm{~K}$, as well as $160 \mathrm{~K}, 42 \mathrm{~K}$, $33 \mathrm{~K}$ and $29 \mathrm{~K}$ proteins in caruncle). The $\mathrm{Ca}^{2+}$. dependent inhibition of phosphorylation has been reported in guinea pig heart [12]. The inhibition may be attributed to the presence of $\mathrm{Ca}^{2+}$-dependent phosphatase. Another possibility is that $\mathrm{Ca}^{2+}$ changes conformations of the substrate proteins, thereby reducing their phosphorylated sites. Whatever the mechanism is, the $\mathrm{Ca}^{2+}$-dependent inhibition of phosphorylation, as well as the limited PKC substrate distribution, suggests that cow placenta and caruncle have incomplete PKC-mediated signal transduction system, since $\mathrm{PKC}$ requires phosphorylation of substrate proteins to exert its physiological functions.

It is also noteworthy to mention that $\mathrm{E}_{2}$ receptor concentrations in placenta and caruncle show remarkably lower levels than those in pregnant uterus, despite the fact that placental tissues are responsible for $E_{2}$ synthesis during the course of pregnancy. Cow placenta is originated from fetal chorion whereas caruncle is of uterus origin. In spite the different origins, both tissues have similar $E_{2}$ receptor concentrations.

Considering all these results together, it is conceivable to assume that the signal transduction systems mediated by $\mathrm{PKC}$ and $\mathrm{E}_{2}$ receptors are suppressed functionally in cow placenta and caruncle. The fetus is an allograft for the mother, and the placenta serves as a barrier to the entry of maternal immune effector molecules or cells into the fetus [6]. Both PKC [3] and $E_{2}$ [21] are involved in the regulation of immune responses. The suppression of PKC phosphorylation and lowered $\mathrm{E}_{2}$ receptor concentrations may be related to the immunebarrier function of the placenta.

Although $\mathrm{PKC}$ and $\mathrm{E}_{2}$ receptors are two major mediators in signal transduction systems in diverse tissues, particularly in the reproductive tissues, studies in cow placenta and caruncle of other mediators such as cyclic AMP-dependent protein kinase, progesterone receptors and $\mathrm{G}$ proteins, in addition to the identification of the PKC substrates and the functional aspects of the phosphorylated forms, are required for overall understanding of the regulation of the placental transport system.

ACKNOWLEDGEMENTS. I am grateful to Dr. K. Barrymore for his critical reading of the manuscript. This study was supported in part by a Grant-in-Aid (Bio Media Program) from the Ministry of Agriculture, Forestry and Fisheries of Japan (91-IV-1-12). 
REFERENCES

1. Albert, K. A., Wu, W. C.-S., Nairn, A. C., and Greengard, P. 1984. Inhibition by calmodulin of calcium, phospholipiddependent protein phosphorylation. Proc. Natl. Acad. Sci. U.S.A. 81: 3622-3625.

2. Beckman, W. C., Hudseph, D. A., Golding, T., Hubbert, L., Akkerman, J., and Korach, K. S. 1989. Bimodal nuclear estrogen receptor binding: synchrony in athymic mouse uterus and human breast tumor xenografts. Endocrinology 124: 2651-2658.

3. Berry, N. and Nishizuka, Y. 1990. Protein kinase C and T cell activation. Eur. J. Biochem. 189: 205-214.

4. Bradford, M. M. 1976. A rapid and sensitive method for the quantitation of microgram quantities of protein utilizing the principle of protein-dye binding. Anal. Biochem. 72: 773-775.

5. Burton, K. 1956. A study of the conditions and mechanism of the diphenylamine reaction for the colorimetric estimation of deoxyribonucleic acid. Biochem. J. 62: 315-323.

6. Chaouat, G., Kolb, J. P., and Wegmann, T. G. 1983. The murine placenta as an immunological barrier between the mother and the fetus. Immunol. Rev. 75: 31-60.

7. Hannun, Y. A., Loomis, C. R., Merrill, A. H., and Bell, R. M. 1986. Sphingosine inhibition of protein kinase $C$ activity and phorbol dibutyrate binding in vitro and in human platelets. J. Biol. Chem. 261: 12604-12609.

8. Katoh, N. 1990. Protein kinase C and its endogenous substrate proteins in bovine mammary gland. J. Dairy Sci. 73: 1201-1207.

9. Katoh, N. 1991. Increased nuclear type II estradiol receptor concentrations in rat spleen during the course of pregnancy. J. Vet. Med. Sci. 53: 975-979.

10. Katoh, N. and Kimura, K. 1989. Decreased protein kinase $\mathrm{C}$ activity in fatty liver from cattle. Am. J. Vet. Res. 50: 1489-1492.

11. Katoh, N., Shimbayashi, K., Abe, K., and Sakurada, K. 1991. Decreased estradiol receptor concentrations in ethionine-induced fatty liver of rats. Toxicol. Lett. 58: 279-285

12. Katoh, N., Wise, B. C., Wrenn, R. W., and Kuo, J. F. 1981. Inhibition by adriamycin of calmodulin-sensitive and phospholipid-sensitive calcium-dependent phosphorylation of endogenous protein from heart. Biochem. J. 198: 199-205.

13. Katoh, N., Wrenn, R. W., Wise, B. C., Shoji, M., and Kuo, J. F. 1981. Substrate proteins for calmodulin-sensitive and phospholipid-sensitive $\mathrm{Ca}^{2+}$-dependent protein kinases in heart, and inhibition of their phosphorylation by palmitoylcarnitine. Proc. Natl. Acad. Sci. U.S.A. 78: 4813-4817.

14. Kikkawa, U., Minakuchi, R., Takai, Y., and Nishizuka, Y. 1983. Calcium-activated phospholipid-dependent protein kinase (protein kinase C) from rat brain. Methods Enzymol. 99: 288-298.

15. Kimura, K., Katoh, N., Sakurada, K., and Kubo, S. 1984. Phospholipid-senstive $\mathrm{Ca}^{2+}$-dependent protein kinase system in testis: localization and its endogenous substrates. Endocrinology 115: 2391-2399.

16. Kimura, K., Sakurada, K., and Katoh, N. 1985. Inhibition by gossypol of phospholipid-sensitive $\mathrm{Ca}^{2+}$-dependent protein kinase from pig testis. Biochim. Biophys. Acta 839: 276-280.

17. Kuo, J. F., Shoji, M., Girard, P. R., Mazzei, G. J., Turner, R. S., and Su, H.-D. 1986. Phospholipid/calcium-dependent protein kinase (protein kinase C) system: a major site of bioregulation. Adv. Enzyme Reg. 25: 387-400.

18. Nishizuka, Y. 1984. The role of protein kinase C in cell surface signal transduction and tumor promotion. Nature (Lond.) 308: 693-698.

19. Notides, A. and Gorski, J. 1966. Estrogen-induced synthesis of a specific uterine protein. Proc. Natl. Acad. Sci. U.S.A. 56: 230-235.

20. Qi, D.-F., Schatzman, R. C., Mazzei, G. J., Turner, R. S., Raynor, R. L., Liao, S., and Kuo, J. F. 1983. Polyamines inhibit phospholipid-sensitive calmodulin-sensitive $\mathrm{Ca}^{2+}$ dependent protein kinases. Biochem. J. 213: 281-288.

21. Schuurs, A. H. W. M. and Verheul, H. A. M. 1990. Effects of gender and sex steroids on the immune response. $J$. Steroid Biochem. 35: 157-172.

22. Steinschneider, A., Rao, M. C., Khan, I., McLean, M. P., and Gibori, G. 1991. Calcium-calmodulin and calciumphospholipid-dependent phosphorylation of membrane fraction proteins related to the tropic regulation by estradiol in the corpus luteum. Endocrinology 128: 263-272. 